\title{
The Societal Value of Art and Music in the Bapedi Culture and the Implications for Music in Healing as a Cultural Phenomenon
}

\author{
Morakeng Edward Kenneth Lebaka \\ Department of Art \& Music, College of Human \\ Sciences University of South Africa (Unisa), Pretoria, South Africa
}

\begin{abstract}
Bapedi people's art and music are a functional and necessary part of everyday life and it would be impossible to understand Bapedi culture without an understanding of their art and music. Within Bapedi people's cultural context, art and music give life to the values, emotions and daily customs of the Bapedi people. The purpose of this article was to investigate the social, cultural and religious functions of art and music within Bapedi people's cultural context, and to place Bapedi people's indigenous art in its social context rather than to discuss aesthetic appeal, stylistic zones, and the formal qualities of art objects. Further, it seeks to discover a) the implications for music in healing as a cultural phenomenon; and how art and music are a functional and a necessary part of the daily lives of Bapedi people. The study used a naturalistic approach and the methods of data collection were video recordings of cultural and religious rituals, social ceremonies and celebrations, interviews and observations. The results have shown that in the Bapedi culture, art and music play a pivotal role in many spheres of the Bapedi people's lives. The results have also demonstrated that Bapedi people express their emotions through music, and use music for regulating their emotions.
\end{abstract}

Keywords: Bapedi people, art and music, healing, culture, Sekhukhune district, Limpopo Province, South Africa.

\section{Introduction}

Bapedi people are a Bantu ethnic group residing primarily in Sekhukhune district municipality (see figure 1), Limpopo Province in South Africa, as well as other parts of the country to a lesser extent. They are a pretty peculiar people and hospitable. They are generally helpful and polite, and glad to help confused tourists if asked. In Bapedi society, music is performed as part of Bapedi people's social life and is used to communicate a great variety of messages. Bapedi people find the songs helping them in their religious experience and in calming their emotions. The use of culturally appropriate music $^{1}$ serves as a major means of creating social cohesion, promoting wise behaviour and imparting moral and ethical values. Musical instruments such as membranophones; meropa (drums), chordophones; botsorwane and lekope, idiophones; dipela (mbira), dith/wath/wadi (leg and hand rattles), and aerophones; dinaka (reed-pipes), phalafala (antelope horn), mekuduetane (whistles) are used during cultural and religious rituals, as well as during social ceremonies and celebrations. Indigenous Bapedi songs are communally composed to local tunes and they are accompanied by dancing and clapping of hands.

\footnotetext{
${ }^{1}$ Relevant to the context of this study, Munyaradzi and Zimidzi $(2012, p .193)$ rightly state that the definition of music can depend on the culture or society an individual belongs. Munyaradzi and Zimidzi further point out that music can be defined as the agreement of the people of a culture as to the sounds and the ways of using these sounds that are pleasant or effective. In the same vein, Mkallyah (2018, p.201) writes that "in Africa, the term 'music' relates most frequently to the sounds that focus on social needs".
} 


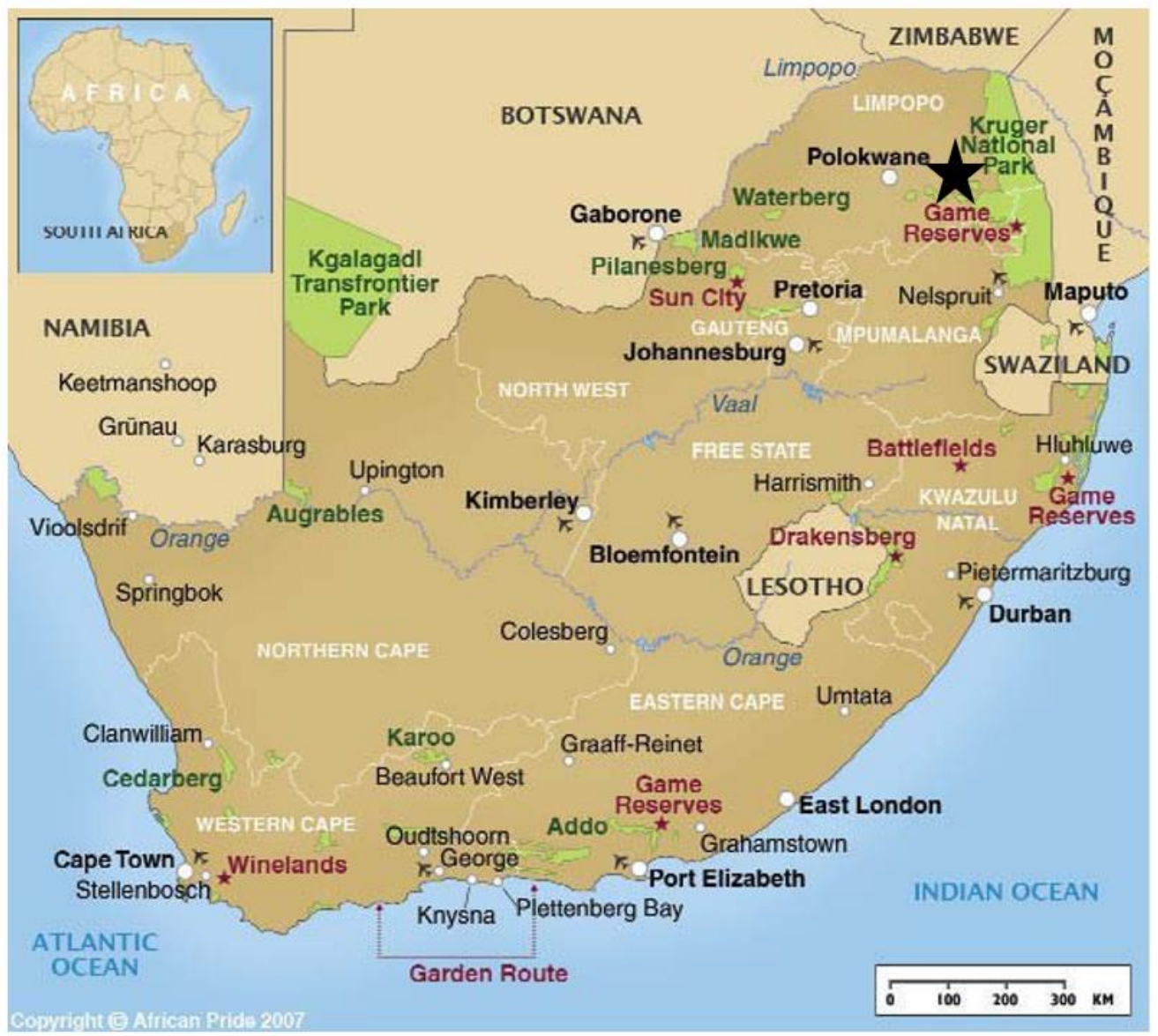

Figure 1: Geographical Location Map of South Africa showing Sekhukhune district municipality in Limpopo Province.

Source: https://showme.co.za/facts-about-south-africa/the-maps-of-south-africal

Date: 23 July 2019

$=$ shows where Sekhukhune district municipality is situated in Limpopo Province.

The choice of the Bapedi people as the context for this research study is primarily motivated by the fact that the researcher belongs to the same group. Given this reality, it is easy to appreciate and assess traditional views, customs and practices as an internal observer. The second reason for choosing this topic relates to the researcher's past experience. This research study is thirdly, motivated by a need to collect and document the social, cultural and religious functions of art and music within Bapedi people's cultural context. The result of this undertaking will be a contribution that could be utilised by posterity. By using Indigenous Knowledge Systems, like the Bapedi culture, a data bank could be built for future scientific research. Three interrelated research questions therefore guided this study; 1) What makes art and music so important in Bapedi society? 2) What is the role, the function and the position of art and music in the daily lives of Bapedi people? and; 3) What are the implications for music in healing as a cultural phenomenon? The purpose of this study is to address the above questions with the view to show the importance of understanding, respecting and acknowledging Indigenous Knowledge Systems. This article comprises four parts in total, which deal with the following issues: The next section will describe the theoretical framework underpinning the study. The discussion will commence by discussing extant literature on the importance of music in society. It then moves on to the research methodology. Next, the results of the study will be 
presented, followed by the discussion of results. Finally, the last section would basically sum up research findings and conclusions of the study, and contains the conclusions arrived at in the study and recommendations for further studies.

\section{Theoretical Framework}

In this study, the author adopts a critical lens toward the 'Sociocultural Theory'. Sociocultural theory grew from the work of seminal psychologist Lev Vygotsky who believes that parents, caregivers, peers, and the culture at large are responsible for developing higher order functions (Vygotsky, 1978). According to Vygotsky, learning has its basis in interacting with other people. Vygotsky theory also stresses the importance of play in learning. According to him, types of play that can further learning include role-playing, games, and reinactments of real events. He believes that cultures can vary so dramatically and each culture presents unique differences. This theory considers how education occurs within the totality of a specified culture, including all the realms of a given society (Mwinzi, 2015, p.678). The Sociocultural theory is applicable to this study, as it deals with communalism, holisticism, preparationism, perennialism and functionalism as the base of African thought which is perceived in this study as Indigenous Knowledge Systems. It is in line with Bapedi people's music tradition in the Bapedi cultural setting. More specifically, the theory of sociocultural seeks to know, understand and prescribe apt practices of pedagogy (Mwinzi, 2015, p.678). Tudge and Scrimsher (2003) observe that, Vygotsky was not only interested in what more knowledgeable others brought to the interaction, but also in what the child himself or herself brought to the interaction, as well as how the broader cultural and historical setting shaped the interaction at large.

Vygotsky's theory is adopted for this study because it is generally consistent with the objectives of the present study. My interpretation of Vygotsky's research framework in relation to Bapedi people's cultural context is that in the Bapedi culture, during the transmission process of indigenous Bapedi songs, parents, caregivers, peers and the community at large play a pivotal role to make enculturation process a reality and a success, and learning music within Bapedi people's cultural context has its basis in communalism and interacting with other people. In this interpretation, communal music-making is viewed as a cultural activity which reveals a group of people organizing and involving themselves with their own communal relationships (Chernoff, 1979). The second alternative interpretation would be that in the Bapedi society, some if not all community members are engaged in some recurrent activities in which any member of the community joins regularly with others outside the community. Consistent to this interpretation, Gearing et al $(1975, \mathrm{pp} .2 \& 5)$ opine that "any person who is to become a participant in any recurring event enters as a newcomer and later becomes an old hand". He further asserts that "in the contemporary world, every person lives in two kinds of social systems, daily moving into and out of events which make up one or more localized worlds and a wider world" $(1975$, p.6). These scholars suggest that "an adequate sample of events must include events which are parts of such localized systems singly and in some combinations other events which are parts of such wider networks, and still others which are parts of both in some interpenetrating mix" (Gearing et al, 1975, p.6).

Like the objectives and recommendations of this study, Vygotsky's research framework 'Sociocultural Framework' is probably the earliest effort encouraging ethnomusicologists to invest more interest in music, culture and identity, as well as in communal music-making and learning by doing. It posits that culture constitutes concrete manifestation of human social processes and historical development. Gindis (1999, p.39) expressed firm conviction that Vygotsky's scientific legacy contains a theoretical framework that might integrate all branches of contemporary education. According to Gindis (1999, p.39), the socially, culturally, and developmentally oriented theory of Vygotsky has the potential to unify, restructure, and promote education which is culturally embedded. In my view, Vygotskian framework can be viewed as an educational theory which enhances educational practice and a critical discourse for understanding Indigenous Knowledge Systems. Using this framework, four questions were explored. These questions refer to music, culture, heritage and identity. The present study will contribute to a clearer understanding of the role of art and music in Bapedi society based on communalism, holisticism, preparationalism, perennialism and functionalism as advocated by Vygotsky. The next section focuses on the previous related studies.

\section{Previous Related Studies}

Studies of the importance of music in society, among them by Mbaegbu (2015), Gregory (1997), Rager (2008), Reimer (2002), Dube (1996) and Nnamani (2014), have dealt with music as an integral part of the societies that perform it. In his study of the effective power of music in Africa, Mbaegbu (2015, p.176) found that "music plays an indispensable role in the being of Africans at work, in politics, in their socio-economic engagements, in religious worship, integral development and in their moral life". His study has also demonstrated that African music is one of the cultural characteristics that make the 
African who he is as a distinct cultural being in the world, for it binds Africans together and gives them common characteristics. Attesting to these findings, Gregory (1997, pp.123-124) writes: "In many societies music is not an independent art form to be enjoyed for its own sake, but is an integral part of the culture". He further mentions that "music may accompany every human activity from the cradle to the grave, including lullabies, games, dancing, work, healing, battle, rites and ceremonies, including weddings and funerals". Gregory is of the opinion that "Africa has hundreds of different societies, each with their own traditions and with different roles for music, but in the majority of them music forms an integral part of all activities" (1997, p.124). This view is further articulated by Dube (1996, p.101) who observes that "music is found in specific contexts like rites of passage, for example birth, marriage and weddings, death, house-warning activities, beer drinking, war, coronation, homage to a ruler, politics, hunting, harvesting and general work, vulgar play, boasting, herding, lullabies, children's play, and royal praises". Further exploring this finding, Dube (1996, p.110) writes that "popularly known as chimurenga music in Shona society, music performance was used in the war to instil determination, inspiration and hope among fighters and everyone who participated. Furthermore, Dube (1996, p.115) argues that "in traditional society, music has a direct functional role". In a similar vein, Rager $(2008, p .1)$ points out that "music serves various functions and is used by people of all ages in many ways". Rager $(2008$, p.8) proceeds to reveal that Reimer (2002) also believed that music has a dual role in society. Firstly, to develop talent for those gifted musically and secondly, to develop aesthetic sensitivity to music of all people regardless of their musical talents. According to Reimer, this in turn would benefit society and the art of music which depended upon an understanding public.

Consistent with these observations, Munyaradzi and Zimidzi (2012, p.194) observe that the function of music in a society is another area of importance that brings misunderstandings as some people fail to understand the functions of music in another culture. Munyaradzi and Zimidzi further elaborate that the issue of cultural aspects brings in many differences as cultural beliefs changes the view of many people when it comes to defining music $(2012$, p.194). Nnamani $(2014$, p.304) supports these observations by stating that "in Africa generally, music plays an important part in the lives of the people and one of the major characteristics of African music is that it has function. Nnamani affirms that the various stages of the lifecycle of an individual and the life-cycles of the society are all marked with music (2014, p.304). Furthermore, Nnamani asserts that another important feature of African music is the existence of a wide diversity of singing and dancing styles which seem to create difficulties of understanding and appreciation by those who are not accustomed to the tradition (2014, p.306). According to Nnamani, this diversity is partly due to linguistic factors, for many African music reflect speech mannerisms of the various language groups including common features of speech such as rhythm and intonation (2014, p.306). Nnamani is of the opinion that Africans depend on music as a means of communication within and outside the community $(2014$, p.306). He is convinced that the fact is that the traditional African sees a link in time past, time present and in the future. In his view, this link is however, symbolized by the sound of music (Nnamani, 2014, p.306).

Research about the significance of music in a society has generated diverse beliefs, views, and theories that explore its nature and meaning. Nketia(1976, p.9) and Tracey $(1954$, p.240) state that "the promotion of different types of music in traditional society does not normally require special institutions or places set aside solely for performances of music and dance". These scholars postulate that "performances take place on social occasions and are either integrated with the central events or arranged as background activities". They reckon that "it is institutional life, therefore, that supports traditional music". Corroborating the above findings Ibekwe $(2009$, p.163) observes that music (especially African) by its nature and purpose is a compendium of people's way of life. According to lbekwe, it represents people's tradition and no amount of stereotype conception can undermine its importance in any society. Expanding this further, Allen (2004, p.4) and Schumann (2008, p.34) assert that "music can act as an acute indicator of finely tuned public sentiment, and can also function as a site of both individual and group agency". According to these scholars, music is one of the fundamental mechanisms through which people indicate what they personally enjoy, approve of, identify with, recognise as true, or acknowledge as ethically appropriate. Views such as those expressed by Dickie $(2017$, p.1) and Jayeola (2015, p.102) highlight the impact that music and song. In particular, Dickie (2017, p.1) observes that "music and song have a powerful ability to move people emotionally, and thus have a distinct role to play in a person's worship". In his view, music is one of the major forms of oral art in African societies, and is always performed before an audience. In the same vein, Jayeola (2015, p.102) opines that "African music is one of the cultural indices that make Africans". Further, Jayeola (2015, p.102) elaborates that "African music is a cultural identity that has to do with singing, playing of instruments, dancing and use of various artifacts". Jayeola believes that "traditional music can claim to be the expression or art that is most accessible to human beings in any situation in their lives: crises or calm, work and worship, play or war, recreation or reflection, and has so much influence in the life of an African man and everything we do; even in our traditional occupations like, farming, 
weaving, blacksmith, carpentry, dyeing, hunting" (2015, p.104). Jayeola $(2015$, p.4) remarks further that "in African context, music is implicated in life, and people go all out to use music to communicate, to move, to express emotions and ideas, and to mobilize people or rally their solidarity". According to Jayeola, music performed by every society carries the social cultural nuances and messages of the society.

Taking a different view, Chiang (2008, p.21) argues that Africa experience sickness and healing through rituals of consciousness-transformation whose experiential core is musical. He further states that traditional healing ceremonies serve to heal the sick and are done differently among different communities (2008, p.34-35). He is of the opinion that unlike music therapy, traditional music and healing usually serves as the primary healthcare system in the developing world. He believes that these cultures hold beliefs in the healing power of music that were shaped by their history and cosmology. By reviewing the literature above, it is clear that music in Africa involves language, the customs and values of the society and permeate every facet of human endeavour.

\section{Research Methodology}

A methodological approach in this study comprised of conversational method ${ }^{1}$, Ethnography ${ }^{2}$, and a case study approach, whilst, the fundamental tool of collecting data was primarily oral interviews among traditional Bapedi musicians, video recordings and observations. A total number of thirteen (13) traditional musicians were interviewed for the study. Through my interaction with them, I was afforded the opportunity to get first-hand information and to gain insights on aspects and issues that are often neglected and rarely published. Traditional musicians were interviewed to elicit information on Indigenous Knowledge practices in relation to their music tradition used in the Bapedi culture. Rationale for choosing interviewees was based on their knowledge of different indigenous Bapedi music genres and the musical processes of these music genres as well as their social, cultural and religious functions.

\section{Results}

\section{Social functions}

\section{Music as a tool for creating social cohesion}

During the study, it was observed that in the Bapedi culture, music has the power to unite Bapedi people (see photo 1). It has become evident that Bapedi people use their indigenous songs for social cohesion, to create mutual trust and to cement friendship. Correlating the above, Gregory (1997, p.131) asserts that "music is a powerful means of creating a sense of belonging, either to a particular ethnic group or to a place". Attesting to Gregory's assertion, Mkallyah $(2018$, p.202) states that "the nature of African music performance is based on accompanying different activities in the sense that it is not music just for listening to". He observes that "African music originates from the African community and is an integral part of the community". In addition Ogunrinade (2012, p.109) explains further that "music and every aspect of life activities are inseparable in African setting to the degree that every activities have music attached to it". According to Ogunrinade (2012, p.111), as an integral part of life, music is used in such day to day activities as disseminating information of societal interest and arousing emotion; and for important occasional events like initiation, rituals and coronation ceremonies. Ogunrinade further elaborates that "music is one of the most powerful, the most compelling, and the most glorious manifestations of human cultural heritage" (2012, p.111). The above point is of prime importance with the view of Ebeli $(2016$, p.22) who opines that "the arts of which music is part are a powerful tool of communication". Additionally, Ebeli (2016, p.24) asserts that "throughout history, music and dance provide pleasure, enjoyment and self-esteem to humanity". Mkallyah (2015, p.167) supports these when he states that "to large extent, music helps to change the people's behaviour through their performances, function and contents".

\footnotetext{
${ }^{1}$ Kovach (2010, p.40) describes conversational method as a means of gathering knowledge found within Indigenous research. According to him, the conversational method is of significance to Indigenous methodologies because it is a method of gathering knowledge based on story telling tradition congruent with an Indigenous paradigm. He believes that conversational method involves a dialogic participation that holds a deep purpose of sharing story as a means to assist others.

${ }^{2}$ Calitz $(2017$, p.5) rightly remark that Ethnography is a means of collecting data through participating observation.
} 


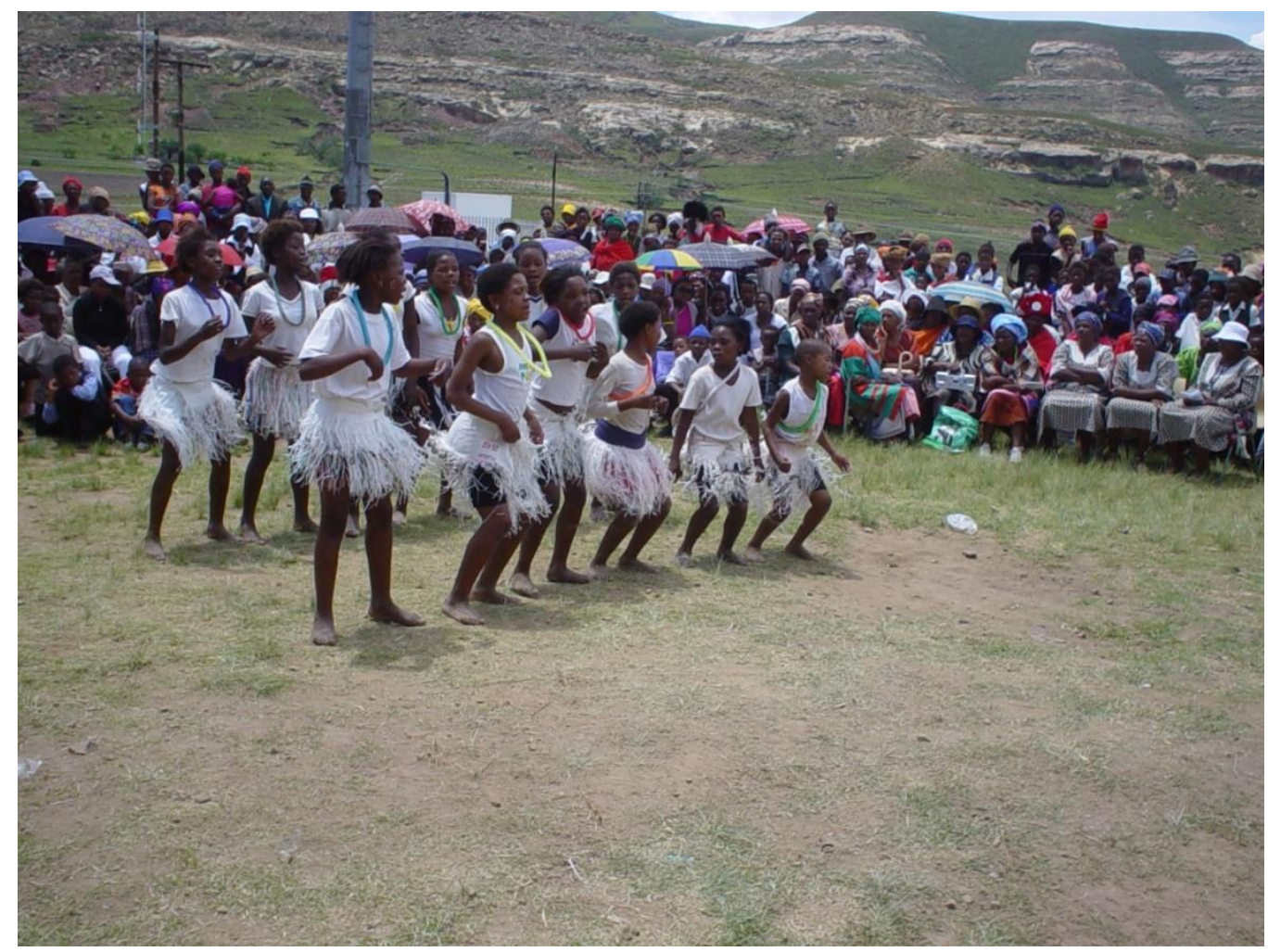

Photo 1

Cultural festival (Dikgageng village; Sekhukhune district, Limpopo Province, 24.09.2018), Photographer: Morakeng Edward Kenneth Lebaka

When participants were asked about the implications for music in healing as a cultural phenomenon it was found that in the Bapedi culture, music in healing and healing in music are conceived as interwoven. Morongwa Angelinah Tshehla explained (12 January 2019) that the importance of music in healing cannot be overemphasized. She further elaborated that music permeates the social life of Bapedi people, and Bapedi society develops its own cultural way of dealing with illness utilizing their indigenous songs.

\section{Cultural functions}

\section{The implications for music in healing as a cultural phenomenon.}

In Bapedi society in particular and in Africa in general, music in healing is an age old tradition. It has been in existence for many centuries before the infiltration of culture and/or acculturation by the Western Christian missionaries, colonialization and Western political expeditions on the African continent. As a knowledge system, it plays a pivotal role in many spheres of the Bapedi people's lives. The above observation is supported by Jayeola $(2015, p .106)$ who unequivocally states that "music, especially traditional music has an answer to whichever direction the mobilization takes". He is of the opinion that culture constitutes the totality of customs, rituals, norms and values that regulate the people's pattern of life. In the same vein, Gregory (1997, p.132) observes that "in many traditional societies, music serves a healing function, has a sacred healing role both for the individual and for society and is believed to facilitate communication with the ancestors and to 
harmonize the forces of the visible and the invisible world". Aluede (2006, p.31) endorses these observations by stating that "the use of music in healing and healing rites in African traditional societies is as old as the origin of African Continent".

Like in many other African societies, in the Bapedi society traditional healers who perform music to appease and to communicate with the ancestors are found (see photo 2). They create music to accompany religious rituals, as well as to reflect on human experiences. They believe that when the ancestors need to be consulted, the most effective way of reaching them is through music and dance (Lebaka, 2017, p.75). Attesting to the above finding, Nnamani (2014, p.305) rightly opines that "in Africa, participation in music is spontaneous and voluntary". He asserts that it is also an obligation imposed by one's membership of a social group or a responsibility attached to one's situation in a society.

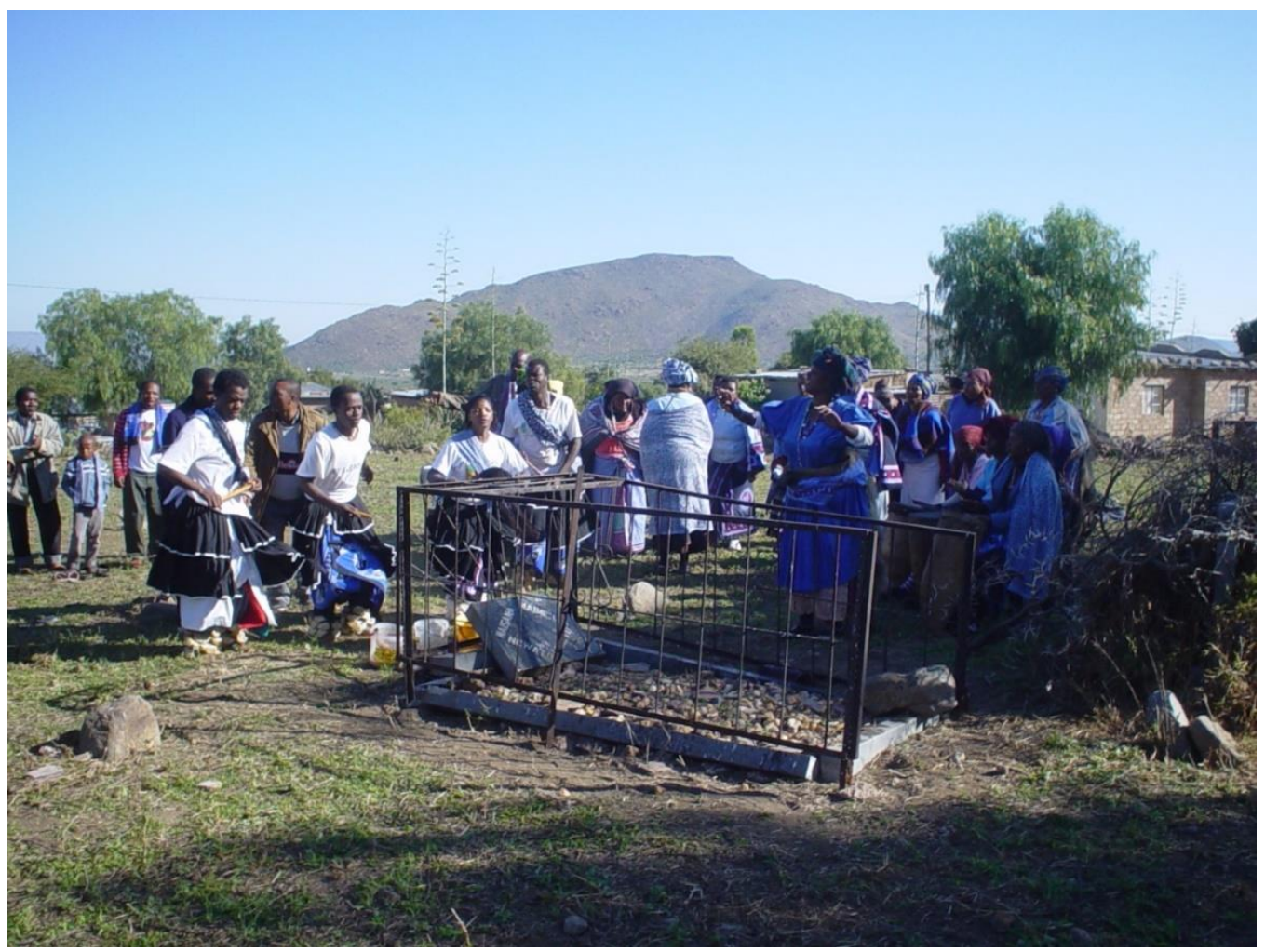

\section{Photo 2}

Dingaka (traditional healers) and Mathasana (trainees) making libations and pouring beer onto the ground; (Mashite village - Schoonoord, Sekhukhune district, 29 September 2007); Photographer: Morakeng Edward Kenneth Lebaka.

Interviews with Malekgopeng Sete (12 January 2019) showed that singing is a mechanism used by traditional healers (see photo 2) to summon the ancestors. Malekgopeng further mentioned that specific songs are sung especially when problems seem particularly difficult to surmount. Concurring with Malekgopeng's views, all interviewees were in agreement that music which is performed during malopo rituals tend to energize the traditional healers (dingaka) and trainees (mathasana) to perform effectively. Malekgopeng further mentioned that during the dance itself, the healing power of the dance is shown by both traditional healers and trainees, who after reaching a state of trance, become spiritually and physically healed. In the same vein, Gregory (1997, p.134) writes that "music may trigger a trance state or calm it, and in different cultures trance may be induced by loud or quiet music, the human voice, drums, or other instruments". According to Gregory (1997, p.134), possession is associated everywhere with music and dance, and these both play their part in inducing trance. Gregory further emphasizes that "often music and dance may act together to produce the emotional state favourable to trance". 


\section{Entertainment}

In African societies, music making is generally organized as a social event (Phibion, 2012, p.2). Phibion continues to emphasize that "music is part of culture and culture influences music" $(2012, p .1)$. Through oral interviews, it was established that indigenous Bapedi songs are also performed to express happiness and for entertainment (see photo 3 ).

The above observation is enriched by Ramadani's (2017, p.249) assertion that "music plays an important role in everyday life, and through music, communication is as natural as conservatory, and as ideal as the mobilization". Ramadani (2017, p.249) further advocates that "the value of music is presented in all musical works which are estimated for the message transmit to the public".

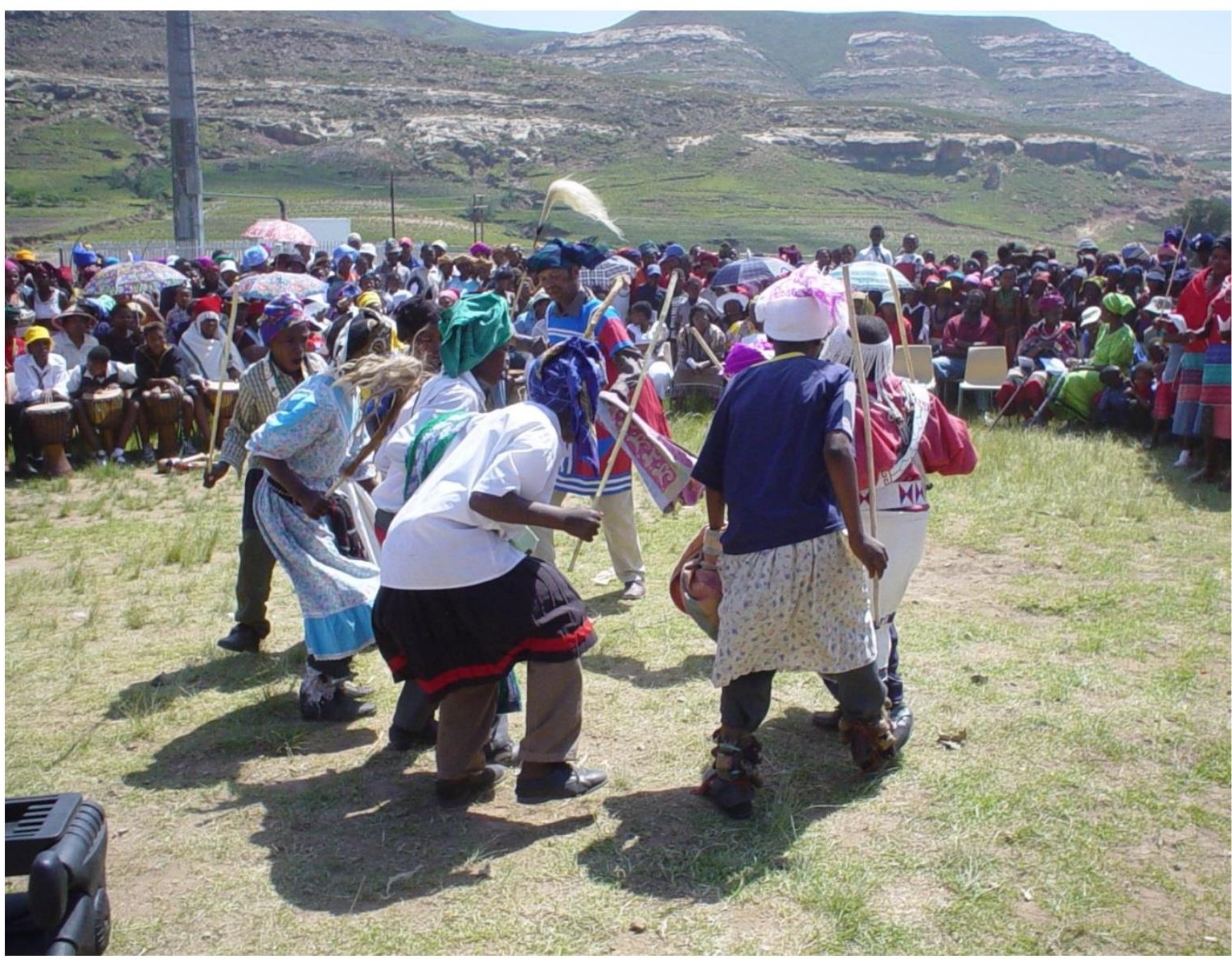

Photo 3

Cultural festival (Dikgageng village; Sekhukhune district, Limpopo Province, 24.09.2018), Photographer: Morakeng Edward Kenneth Lebaka

Among Bapedi people, entertainment songs are quite popular. Wedding songs, for example, are meant for entertainment but have also cohesive and social functions. Bapedi people perform wedding songs to; 1) reinforce the importance of family and community solidarity; 2) reinforce the value of marriage as a sacred union; 3 ) reinforce the importance of perseverance in marriage; 4) reinforce the roles of each spouse in married life; and 5) for entertainment purposes (Lebaka, 2017, p.192). Some songs are sung by community members to accompany tasks such as food preparation, and merry making that takes 
place once all rituals have been performed. Very often, the texts of these songs are not without relevance to the ceremony and issue of marriage. Mkallyah (2015, p.162) captures this notion most succinctly when he writes that "there are songs meant for the bridegroom, and songs for the actual wedding celebration". For him, both of these wedding songs have specific roles to play in society. Mkallyah $(2015, \mathrm{p} .162)$ further elaborates that these songs teach young women how to live with their husbands, and men how to live with their wives. In his view, the celebratory mood associated with these songs stem from the functions for which the songs were designed and performed - a happy occasion. The following song (table 1 ) is an example of entertainment songs sung during wedding ceremonies.

\section{Song text and translation}

\begin{tabular}{|c|c|}
\hline Original Sepedi stanzas & English translation \\
\hline 1. Dali moratiwa & 1. Darling, sweetheart \\
\hline 2. Kgale re ratana & 2. It has been a long time that we were in love, \\
\hline 3. A ko nthekele ring & 3. Please buy me a wedding ring, \\
\hline 4. Wena o bapala ka nna & 4. You are a playing a fool out of me \\
\hline 5. Gona bjale & 5. Very soon, \\
\hline 6. Ke ya tsamaya & 6. I will be leaving, \\
\hline 7. Ke ya tsamaya & 7. I will be leaving, \\
\hline 8. Ke ya kgole kgole & 8. I am going far away \\
\hline 9. Kgole le legae & 9. Far away from home, \\
\hline 10. Wena o bapala ka nna & 10. Because you are playing a fool out of me. \\
\hline
\end{tabular}

Table 1: Sepedi with English translation of 'Dali moratiwa' (Darling, sweetheart) song for entertainment sung during wedding ceremonies.

In support of the above observations, Gregory $(1997$, p.130) states that "ceremonies for individual members of the society are also important, and music is an essential element of every marriage, initiation ritual, and funeral in most cultures". He stresses that "the music in many ceremonies and dances is thus speaking directly to the participants". Gregory (1997, p.135) goes a step further by emphasizing that "in many societies, people enjoy music, singing, and dancing independently of any celebration and festival". Gregory is of the opinion that "the effectiveness of the music thus depends very much on the context, but ultimately it depends upon the music".

\section{Music as a platform for promoting wise behaviour}

During the study, it was further observed that indigenous Bapedi songs are teaching songs, and are used to promote community well-being. It has emerged from this study that these songs are more educational than for purposes of leisure or recreation. The impression created during interviews and observations was that, Bapedi people sing these songs to build moral and ethical values in the society. Photo 4 below shows the caregivers of the initiates (baditi) and the intiates in between the caregivers, welcomed back home after they have satisfied all the requirements for the initiation school. The caregivers sing an initiation song characterised by themes which are educative either by use of direct statements or by use of idioms, metaphors and proverbs that are poetically structured to promote wise behaviour. 


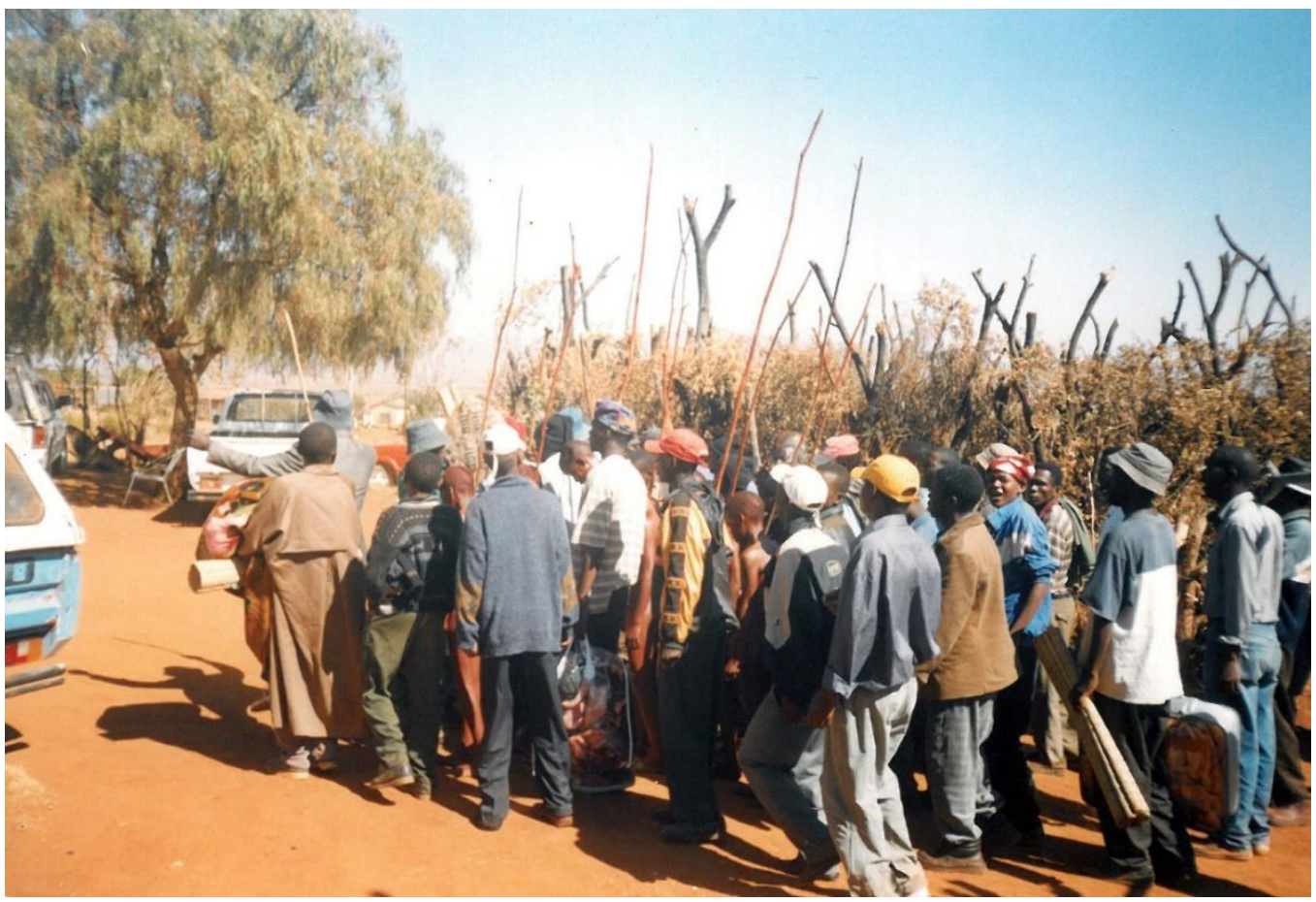

\section{Photo 4}

Initiates welcomed back home (Kotsiri village; Sekhukhune district, Limpopo Province, 13.07.2019), Photographer: Morakeng Edward Kenneth Lebaka

From the observations and interviews, it was established that indigenous Bapedi songs bear advice which seeks to promote cultural heritage and inspire respect. During my field research, I have also observed that Bapedi people sing their songs to promote correct behaviour, exhort morals through condemnation of indecency and inculcate tribal values through advice to observe good behavioural value systems. This observation is in line with the opinion of Oboneng Masha (personal communication, 24 September 2018), who said that "in the Bapedi culture, traditional music education is a systematic process informed by the concept of music as a social experience as well as an agency for the management of people and society".

\section{Religious functions}

\section{Music as a vehicle of imparting moral and ethical values}

Religious music in the Bapedi culture is sacred and is regarded as having extraordinary power. Traditional Bapedi musicians create music to address issues of societal concern and moral and ethical values (see table 2). During the performance, the proverbs are normally very contextual in that they could mean different things in different situations. Some songs are characterized by metaphorical language.

\section{Song text and translation}

\begin{tabular}{|c|c|}
\hline Original Sepedi stanzas & English translation \\
\hline 1. A ke nyake ngwanake a roga batho. & 1. I don't want my child to curse people \\
\hline 2. Hleng o roga batho ba bagologolo & 2. He is cursing the elderly people, \\
\hline
\end{tabular}




\begin{tabular}{|l|l|l|}
\hline 3. A ke nyake ngwanake a roga batho, & 3. $\begin{array}{l}\text { don't want my child to curse people, } \\
\text { mampelebele, }\end{array}$ \\
4. Heng o roga batho ba bagologolo & 4. He is cursing the elderly people
\end{tabular}

Table 2: Sepedi with English translation of 'Ga ke nyake ngwanake a roga batho' (I don't want my child to curse people) song for imparting moral and ethical values.

The purpose of singing the above song is to impart moral and ethical values. The central message in this song is that children or the youth should respect elderly people. The singer is not happy about his child because he is not respectful. $\mathrm{He}$ is offending and provoking elderly people, and is causing himself bad-luck. During oral interviews, it was established that in the Bapedi culture, there is a general belief that the consequences of cursing elderly people is bad-luck. The song is short, characterized by repetition, and the tone is that of a lament, as the singer sounds to be disappointed by the child, disillusioned and demoralised.

Interviewees were asked whether indigenous Bapedi music has an impact on morals and ethical value systems within Bapedi society. It was found that Bapedi people are successful in sustaining and retaining a high standard of living in terms of respect, hierarchy and cohesion because of their indigenous songs. The impression created during interviews and observations was that in the Bapedi society, social and ethical values are communicated through indigenous Bapedi songs, while the content is largely dictated by current concerns and the way Bapedi people approach them. It has emerged from this study that Bapedi people are guided by complex sets of moral and ethical values and beliefs that are historical and cultural.

Corroborating the above observations, Mbaegbu (2015, p.182) opines that "in traditional African society, people's notion of morality go a long way to influence their music". In his view, it is therefore not usual for the African to make merry for their achievements especially when such goals are attained with their physical ability but they insist on justice and fairness in such contests (2015, p.182). Mbaegbu further elaborates that "African music upholds African morality and the same African music which upholds morality do contain some elements that derogates or instil bad morals in African society". He stresses that "while morality sets the pace, African music upholds good morals and denounces some bad ones". These viewpoints are supported by Gregory (1997, p.137) who observes that "in some societies, religion has been the main force behind the development of music, while other religions use no music and may even disapprove of music".

\section{Discussion}

From the above discussions, it is evident that in the Bapedi society, art, music and dance have a much greater purpose for either the community or group. The results yielded thus far have shown that in the Bapedi culture, music and dance are a way of life and not just a form of entertainment. Based on the findings of this study, it is evident that Bapedi culture is deeply rooted in its music, and music is an integral part of the Bapedi culture, with various ceremonies being preceded by some sort of music. In this study we observe that indigenous Bapedi songs are sung to communicate a great variety of messages, calm emotions, create social cohesion, promote wise behaviour and impart moral and ethical values, and serves a healing function. With regard to the relationship between music and dance, the enquiry has revealed that in the Bapedi culture, no real separation exists between music and dance. These results suggest that in the Bapedi culture, the performance of indigenous Bapedi songs involve contact with others, strengthens the perception of social cohesion among Bapedi people and collaboration increases and promotes trust between performers/participants. During the study, it was further observed that indigenous Bapedi songs have the potential to make Bapedi people connected. It has emerged from this study that among Bapedi people, music is a very powerful medium, and it is powerful at the level of the social group because it facilitates communication which goes beyond words, enables meanings to be shared, and promotes the development and maintenance of the individual, group and cultural identity. Results of this study further showed that indigenous Bapedi songs can be used to promote appropriate behaviour in vulnerable groups and enhance the quality of life.

It is noticeable that among Bapedi people, communal music-making may enhance self-esteem and promote the development of a range of social and transferable skills. Interviews with traditional Bapedi musicians reveal high levels of knowledge about the societal value of art and music in the Bapedi culture and the implications for music in healing as a 
cultural phenomenon. Analysing the data, it was interesting to note that indigenous Bapedi songs seem to encourage Bapedi people to use their songs to manipulate their own moods, reduce stress, alleviate boredom while undertaking tedious or repetitive tasks, and create environments appropriate for particular kinds of social occasion. It is of considerable interest to note that Bapedi people do not only listen to music, but they are actively taking part in making it. The exposition of this study has also shown that indigenous Bapedi music is embedded into Bapedi society, but is also a reflection of Bapedi society, revealing some of the values that Bapedi society possesses. On the basis of these findings and discussions, it is arguable that music can serve to maintain a collective identity, function as an identity marker and as part of art, and can express feelings and emotions. The results of this study support Ramadani's (2017, p.248) assertion of the relationship between music, culture and identity. He argues that "music plays an important role in the process of production and reproduction of national culture and national identity. He further emphasizes that "song and music unite people in a living organism, where singing, playing instruments together, and dancing creates mutual trust". He is convinced that "music affects people and also people affect music".

\section{Some Concluding Thoughts}

In conclusion, it is clear that Bapedi people use their music for various functions: to create social cohesion, promote wise behaviour and impart moral and ethical values. The results of this study confirm that through the songs, Bapedi people express their views of all aspects of life. In this study, I have argued that art and music are integral part of Bapedi society. I have also argued that traditional Bapedi music is one of the characteristics that make Bapedi people who they are. The results of this study provide evidence that art and music play a pivotal role in shaping the cultural identity of the Bapedi people. The literature that has been reviewed demonstrates that indigenous music is a natural phenomenon, has many functions and permeate every facet of human endeavour. The study contributes to the notion that indigenous Bapedi music and culture are inseparable. The results yielded thus far have shown that the use of music in healing and the societal value of art and music help to identify the Bapedi culture. Indications from the investigation suggest that Bapedi people should continue to use art and music performances to preserve and develop the Bapedi history and societal beliefs of the Bapedi culture.

\section{References}

[1] Aluede, C. O. (2006). Music Therapy in Traditional African Societies: Origin, Basis and Application in Nigeria. Journal of Humanities and Ecology, Volume 20, Number 1, pp. 31-35.

[2] Allen, A. (2004). Music and politics in Africa. Social Dynamics, Volume 30, Number 2, pp. 1-19.

[3] Dickie, J. (2017). Singing the Psalms: Applying principles of African music to Bible translation. Scriptura Volume 116, pp. 1-16.

[4] Dube, C. (1996). The changing context of African music performance in Zimbabwe. Zambezia XXIII (II), pp. 99-120.

[5] Calitz, C. J. (2017). Healing liturgy: The role of music and singing. Verbum et Ecclesia, Volume 38, Number 1, pp. 1-9

[6] Chernoff, J. M. (1979). African rhythm and African sensibility, aesthetics, and social action in African musician idioms. Chicago and London: The University of Chicago Press.

[7] Chiang, M. M. (2008). Research on music and healing in Ethnomusicology and Music Therapy. Masters' thesis, Faculty of the Graduate School of the University of Maryland, College Park, Baltimore County.

[8] Ebeli, E. A. (2016). Girl child education and enrolment drive: The role of traditional music and dance. Journal of Music and Dance, Volume 6, Number 3, pp. 20-26.

[9] Gearing, F. et al. (1975). Structures of censorship, usually inadvertent: studies in a cultural theory of Education. American Anthropological Associiation, Volume 6, Number 2, pp. 1-9.

[10] Gindis, B. (1999). Vygotsky's Vision: Reshaping the Practice of Special Education for the 21st Century. Remedial and Special Education, Volume 20, Number 6, pp. 32-64.

[11] Gregory, A. H. (1997). The roles of music in society: the ethnomusicological perspective. In: Hargreaves, D. J. \& North, A. C. (eds). The Social Psychology of Music, pp. 125-139. New York: Oxford University Press.

[12] Ibekwe, E. U. (2009). The role of music and musicians in promoting social stability in the country. UJAH UNIZIK Journal of Arts and Humanities, Volume 14, pp. 159-174. http://dx.doi.org/10.4314/ujah.v14i3.10.

[13] Jayeola, F. (2015). Indigenous music in Nigeria: Its role towards National Development. FUNAI Journal of Humanities and Social Sciences, Volume 1, Number 2, pp. 102-109. 
[14] Kovach, M. (2010). Conversational Method in Indigenous Research. First Peoples Child \& Family Review, Volume 5, Number 1, pp. 40-48.

[15] Lebaka, M. E. K. (2017). Transmission Processes of Indigenous Pedi Music. Finland: University Library of Jyvàskylà: Jyväskylä.

[16] Mbaegbu, C. C. (2015). The effective power of music in Africa. Open Journal of Philosophy, Volume 5, pp. 176-183.

[17] Mkallyah, K. (2015). Tanzanianisation and Practice of Indigenous Music Traditions in Church Worship in Dar es Salaam. International Journal of Humanities and Social Science, Volume 5, No.2, pp. 156-168.

[18] Mkallyah, K. (2018). The Emergence and the use of indigenous Tanzanian music traditions in Christian worship in Dar es Salaam, Tanzania. International Journal of Humanities and Cultural Studies, Volume 4, Issue 4, pp. 201-217.

[19] Munyaradzi, G. and Zimidzi, W. (2012). Comparison of Western Music and African Music. Creative Education, Volume 3, No.2, pp. 193-195.

[20] Mwinzi, J. M. (2015). Theoretical Frameworks and Indigenous Knowledge Systems. International Journal of Education Research, Volume 3, Number 2, pp. 677-684.

[21] Nketia, J. H. K. (1976). The place of traditional music and dance in contemporary African society. The World of Music, Volume 18, No. 4, pp. 5-15.

[22] Nnamani, N. S. (2014). The role of folk music in traditional African society: The lgbo Experience. Journal of Modern Education Review, Volume 4, Number 4, pp. 304-310.

[23] Ogunrinade, D. O. A. (2012). Teacher's perception on the incorporation of indigenous music contents into music curriculum in Nigerian schools. African Journal of Education and Technology, Volume 2, Number 1, pp. 108-118.

[24] Phibion, O. S. (2012). Dithlaka music learning and practices through transmission among Batlokwa and Balete of Botswana. Journal of Music and Dance, Volume 2, Number 1, pp. 1-8.

[25] Rager, D. (2008). "The Role of Music in Society Past, Present and Future", Music Faculty Publications, 3. https://engagedscholarship.csuohio.edu/clmusic_facpub/3.

[26] Ramadani, I. (2017). Music, Culture and Identity. Academic Journal of Business, Administration, Law and Social Sciences, Volume 3, Number 1, pp. 248-253.

[27] Reimer, B. (2002). A Philosophy of Music Education. Prentice Hall/Pearson Education, Upper Saddle River, NJ. Pp.14-16.

[28] Schumann, A. (2008). The Beat that Beat Apartheid: The role of music in the resistance against Apartheid in South Africa. Stichproben. Wiener Zeitschrift fur kritische Afrikastudien Nr. 14/2008, 8. Jg., pp. 17-39.

[29] Tracey, H. (1954). The social role of African music. African Affairs, Volume 53, Number 212, pp. 234-241.

[30] Tudge, J. \& Scrimsher, S. (2003). Lev S. Vygotsky on education: A cultural-historical, interpersonal, and individual approach to development. In B. J. Zimmerman \& D. H. Schunk (eds.), Educational Psychology: A century of contributions (pp. 207-228), Mahwah, NJ: Erlbaum.

[31] Vygotsky, L. S. (1978). Mind and Society. Cambridge, MA: Harvard University Press. 